\title{
Spontaneous Convexity Subarachnoid Hemorrhage Caused by Internal Carotid Occlusion: Radiological Features
}

\section{Hemorragia subaracnóidea espontânea na convexidade causada por oclusão da carótida interna: Características radiológicas}

Benedito Jamilson Araújo Pereira ${ }^{1,2}$ Radmila Agra Cariry Targino de Holanda ${ }^{2}$ José Targino Neto ${ }^{2}$ Luciano Ferreira de Holanda 2,3

\footnotetext{
1 Department of Neurosurgery, Centro Especializado em Neurologia e Neurocirurgia Associados (CENNA), Hospital Beneficência

Portuguesa de São Paulo, São Paulo, SP, Brazil

2 Department of Neurosurgery, Divisão de Neurocirurgia, Hospital

Antônio Targino, Campina Grande, Paraíba, PB, Brazil

${ }^{3}$ Department of Medical Sciences, Faculdade de Medicina,

Universidade Federal de Campina Grande (UFCG), Paraíba, PB, Brazil
}

\begin{abstract}
Address for correspondence Benedito Jamilson Araújo Pereira, MD, Rua Martiniano de Carvalho 669, apto. 1.105, Bela Vista, São Paulo, SP, 01321-001, Brazil (e-mail: benedito.jamilson@hotmail.com).
\end{abstract}

Arq Bras Neurocir 2020;39(1):16-17.

\begin{abstract}
Keywords

- spinal hemorrhage

- carotid stenosis

- skull tomography

Resumo

Palavras-chave

- hemorragia subaracnódea

- estenose de carótida

- tomografia de crânio

A 79-year-old patient was admitted to the emergency room with transitory monoparesis in the left hand and dysphasia. The brain computed tomography (CT) and magnetic resonance imaging (MRI) showed a spontaneous right convexity subarachnoid hemorrhage (CSAH). Digital subtraction angiography (DSA) confirmed an asymptomatic occlusion of the right internal carotid artery (ICA). Cases related to stenosis have already been described, but there is no similar report of a case related to occlusion, even though the pathophysiology of both entities is similar. Atraumatic $\mathrm{SAH}$ has been associated with intracranial and extracranial artery stenosis.

Paciente de 79 anos foi admitida na sala de emergência, com monoparesia braquial transitória à esquerda e disfasia. O exame de tomografia cerebral (TC) e ressonância magnética mostraram uma hemorragia subaracnóidea na convexidade no hemisfério direito (cSAH). A angiografia por subtração digital confirmou uma oclusão da artéria carótida interna $(\mathrm{ACl})$ direita assintomática. Casos como esses relacionados à estenose já foram descritos, porém, relacionados à oclusão, não há relato semeIhante, embora a fisiopatologia de ambas as entidades seja semelhante. CSAH tem sido associada à estenose de artérias intracraniana e/ou extracraniana. ${ }^{1}$
\end{abstract}

\section{Case Report}

A 79-year-old patient was admitted to the emergency room with transitory monoparesis in the left hand and dysphasia. The brain computed tomography (CT) ( - Fig. 1Ac) and magnetic resonance imaging (MRI) (- Fig. 1D-F) showed a spontaneous right convexity subarachnoid hemorrhage (CSAH). Digital subtraction angiography (DSA) received

May 20, 2019

accepted

August 21, 2019
DOI https://doi.org/

10.1055/s-0039-1698817. ISSN 0103-5355.
Copyright $\odot 2020$ by Thieme Revinter

Publicações Ltda, Rio de Janeiro, Brazil
License terms

(c) $(1) \$$ 



Fig. 1 (A-C) Axial, coronal and sagittal cranial computed tomography (CT) showing a hyperdense cortical lesion corresponding with a right convexity subarachnoid hemorrhage; (D-F) magnetic resonance imaging (MRI): axial T1-weighted gradient echo sequence image showing subacute right sulcal subarachnoid hemorrhage.
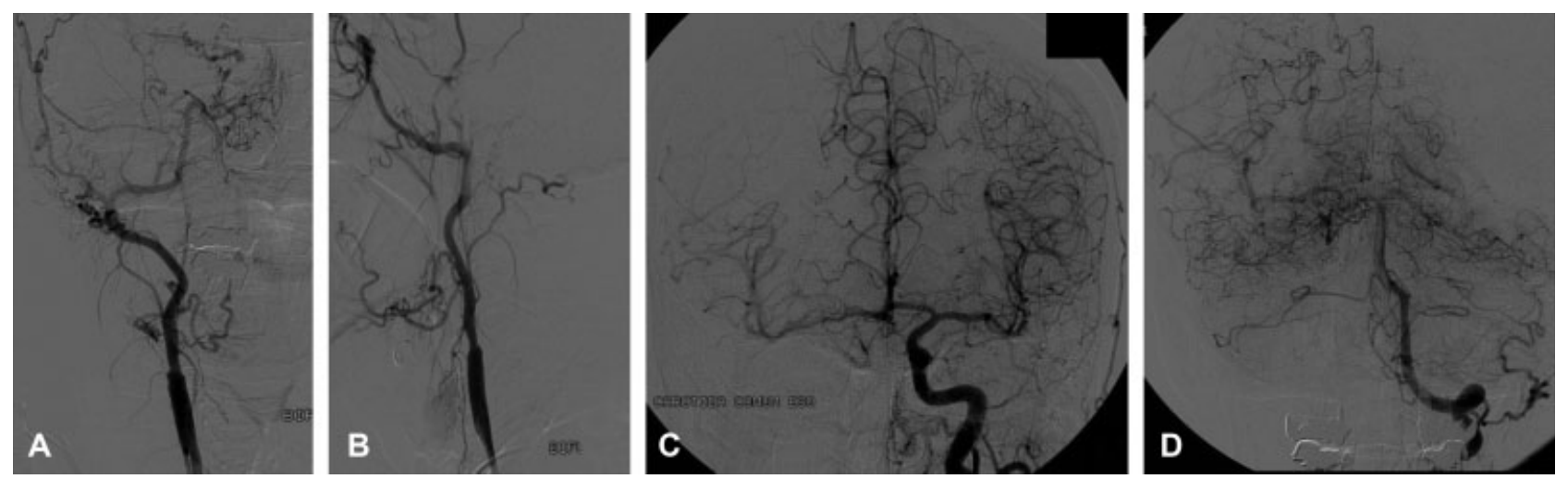

Fig. 2 Digital subtraction angiography (DSA): (A-B) antero-posterior and profile DSA of the right common carotid artery (CCA) showing occlusion of the right internal carotid artery (ICA); (C-D) vascularization of the right cerebral parenchyma by collateral circulation through the polygon of Willis, via the anterior and posterior communicating arteries respectively.

confirmed an asymptomatic occlusion of the right internal carotid artery (ICA) (- Fig. 2). Cases related to stenosis have already been described, but there is no similar report of a case related to occlusion, even though the pathophysiology of both entities is similar. Atraumatic SAH has been associated with intracranial and extracranial artery stenosis. ${ }^{1}$

\section{Conflict of Interests}

The authors have no conflict of interests to declare.

\section{Reference}

1 Chandra RV, Leslie-Mazwi TM, Oh D, Mehta B, Yoo AJ. Extracranial internal carotid artery stenosis as a cause of cortical subarachnoid hemorrhage. AJNR Am J Neuroradiol 2011;32(03):E51-E52, author reply E53 